\title{
Big Data Analytics for Zakat Administration: A Proposed Method
}

\author{
Muhsin Nor Paizin $^{1 *}$ \\ ${ }^{1}$ Akademi Zakat, Pusat Pungutan Zakat, Kuala Lumpur, Malaysia.
}

\begin{abstract}
Big data analytics have altered the corporate landscape in the last several years, presenting firms with both opportunities and obstacles. On one side, employing big data ability to enhance creating, growing, and encouraging deeper consumer connection, which has become a crucial field of business and study. On the other side, the zakat institution is also accountable for zakat collecting activities and is obligated to consistently improve them. Understanding the strategic relevance of data and the actions that may be taken because of data analysis is vital for zakat institutions. Thus, this study objectives are to provide different data kinds to suit the requirements of big data analytics. The research employed an exploratory approach, which comprised secondary research approaches, which required compiling data from previously published primary research. Several sources of information were employed to create this research, including web research and book reviews. As a result, this research proposes four sorts of data namely identification data, quantitative data, descriptive data, and qualitative data, as a preliminary concept of muzakki data requirements for big data analytics with the purpose of enhancing zakat collection by zakat organizations.
\end{abstract}

Keywords: muzakki; customer data requirement; big data analytic; strategic decision making; zakat collection

*Corresponding author: muhsin.paizin@zakat.com.my / muhsin.paizin@ gmail.com Received: July 7, 2021; Accepted: July 30, 2021; Published: September 30, 2021

\footnotetext{
Abstrak: Analisis data besar telah mengubah lanskap perusahaan dalam beberapa tahun terakhir, menghadirkan peluang dan hambatan bagi perusahaan. Di satu sisi, menggunakan kemampuan data besar untuk meningkatkan proses menciptakan, menumbuhkan, dan mendorong koneksi konsumen yang lebih dalam, yang telah menjadi bidang bisnis dan studi yang penting. Di sisi lain, lembaga zakat juga bertanggung jawab atas kegiatan pengumpulan zakat dan berkewajiban untuk meningkatkannya secara konsisten. Memahami relevansi strategis data dan tindakan yang dapat diambil sebagai hasil analisis data sangat penting bagi lembaga zakat. Dengan demikian, tujuan penelitian ini adalah untuk menyediakan jenis data yang berbeda agar sesuai dengan kebutuhan analitik data besar. Penelitian ini menggunakan pendekatan eksplorasi, yang terdiri dari
} 
pendekatan penelitian sekunder, yang membutuhkan kompilasi data dari penelitian primer yang telah diterbitkan sebelumnya. Beberapa sumber informasi digunakan untuk membuat penelitian ini, termasuk penelitian web dan resensi buku. Akibatnya, penelitian ini mengusulkan empat jenis data yaitu data identifikasi, data kuantitatif, data deskriptif, dan data kualitatif, sebagai konsep awal persyaratan data muzakki untuk analisis data besar dengan tujuan meningkatkan pengumpulan zakat oleh organisasi zakat.

Kata kunci: muzakki; persyaratan data pelanggan; analitik data besar; pengambilan keputusan strategis; pengumpulan zakat

\section{INTRODUCTION}

People around the world cannot deny that the Internet and data have changed how businesses operate, how the government functions, education, and even the way people live. Increasing amounts of data are continuously generated with the digitization of most processes, the emergence of new social networking platforms, blogs, and the deployment of different sensors, hand-held and wearable devices, and increased Internet usage. As a result, the rate of data generation has reached a top level, and new types of data are being generated that cannot be stored in existing data storage techniques. Without question, these data represent far more information than has ever been available in the past, thanks to the emergence and popularization of the Internet (Bhadani A. \& Jothimani D., 2016).

Each institution faces stiff competition in today's state of digital marketing. The era of 2021 and Covid-19 ushers in a new era of data-driven decision-making. These methods are now available as customer data management systems, and they produce quantifiable results, as businesses are quickly discovering. However, if those efforts are not well calculated, well planned, and well-aligned with the institution's data management goals and functions, institutions of all sizes risk drowning in this onslaught of data. The ability to manage customer data streams triumphantly is critical to any institution's success today (McKinsey, 2020). Thus, it is critical for any institution to carefully plan the data it will collect, as this data will be beneficial to the institution's success. While discussing muzakki (zakat payer) data, zakat institutions must also plan well to improve the dakwah or marketing process in order to achieve the goal of increasing zakat collection.

Zakat is a major Islamic principle that requires Muslims who are deemed qualified and financially capable to carry out the responsibility to pay it. The zakat principle seeks to assist the poor and reduce poverty from society while also promoting the abolition of greed and selfishness within the Muslim community. Zakat is paid by muzakki, who deducts a prescribed percentage of a financially capable Muslim's income or possessions for the benefit of the community, particularly the poorest members. A zakat institution is typically established within the Muslim community or by the government, depending on the country's laws, to collect and manage zakat funds for the poor (MN Paizin, 2014). The zakat institution manages its collection activities and is expected to improve it regularly in order to improve distributions as well (Sulaiman H. \& Jamil N., 2014). Due to the increasing amount of zakat collected from various sources, the zakat institution must manage and secure an 
overwhelming amount of data daily. One of the highest concentrations of zakat payers in Malaysia is in the state of Federal Territory of Malaysia, where many Muslims' salaries are automatically deducted, a sum of it, for zakat payments. According to the Federal Territory of Malaysia's zakat institution's financial report, there are approximately 378,149 muzakki (zakat payers), totaling RM756 million from January to December 2020, in the Federal Territory of Malaysia alone (PPZ, 2020).

Besides managing the growing muzakki data, the zakat institution utilizes it to improve their zakat collection. As a result, the current rate of growth in the amount of data collected is astounding. A significant challenge for the zakat institution's information technology (IT) department is that this growth rate is rapidly outpacing the institution's ability to manage its data effectively and analyze the zakat data to extract meaningful meaning for improved decision making in order to ensure more effective zakat collection measures. As a result, the evolution of big data is unavoidable (Nugraha F. et al., 2019). Big data manage not only data that is currently stored in traditional databases but also data that is unsuitable for storage in those databases. Thus, there will come a time when access to mountains of muzakki's data will require the zakat institution to develop more effective business strategies and decisions, as an analysis of the massive amount of data will reveal valuable insights into resolving some of the institution's zakat collection and management challenges. This research tries to propose many data types to meet the requirements of big data analytics, including identity data, quantitative data, descriptive data, and qualitative data, as a preliminary concept of muzakki data requirements for big data analytics with the goal of improving zakat collection by zakat institutions

\section{LITERATURE REVIEW}

\section{Zakat}

Zakat is classified into two broad categories: zakat al-Fitr and zakat of wealth. Muslims pay Zakat al-Fitr once a year during the fasting month of Ramadhan. Zakat of wealth is further classified as zakat of business, zakat of savings, zakat of income, zakat of gold, and zakat of investment. According to the Qur'an, there are eight categories of zakat recipients: the needy, the poor, the appointed collector of zakat or "amil," new Muslim converts, people who cannot pay debts, people who are in the state of Allah's cause (fisabilillah), slaves, and the traveler without a home (Ibn as-Sabil) (MN Paizin, 2014).

While zakat has been recognized as worship for individuals, its operations are typically managed by organizations or authorities, referred to as zakat institutions. Zakat institutions serve two critical functions: they collect zakat dues and distribute zakat funds to the beneficiaries (Lubis M. et al., 2011). Thus, the concept of zakat management contributes to a better understanding of why zakat institutions must be properly managed. Apart from that, big data analytics will provide zakat institutions and the government with a transparent analysis of information, avoiding data falsification in order to boost zakat's performance even further. The success of such 
a mechanism is contingent upon the effective implementation of an IT governance framework with a big data maturity model to find out where they are and how they intend to get there (Sulaiman H. et al., 2015).

During the early stages of big data adoption, organizations such as the zakat institution will pause and consider which data sources are valuable, whether they have the capabilities to handle the responsibilities associated with big data management, and how these big data technologies fit into their existing IT infrastructure. These inquiries emphasize the importance of obtaining the best muzakki data for future big data analysis. To successfully implement big data technologies as an analytic tool, the zakat institution must first gain a suitable set of data, which will sustain the institution's big data capability (Halper F. \& Krishnan K., 2013; Moore, 2014). Thus, a zakat institution that implements sound IT governance and attempts to leverage big data analytics is deemed to strengthen its data management capacity and reduce the likelihood of failure in managing the ever-increasing complexity of data associated with zakat collection. A strong analytical process has been emphasized to assist organizations in developing an ecosystem comprising technologies, data management, analytics, governance, and organizational components (Awwad M. S. \& Omoush K. S. A., 2012). The big data analytical process is also critical as a training program for employees, as many zakat institution employees are unaware of the value of data and the strategic decisions that can be made because of data analysis. Thus, big data serves as a critical strategic solution for the zakat institution, optimizing and ensuring that critical information about zakat collection and management is properly managed. By implementing the big data analytical process, this section will detail the stages that an institution must go through when embarking on big data initiatives (Halper F. \& Krishnan K., 2013). This will ultimately increase the benefits of zakat recipients, as well as the business performance and productivity of zakat institutions.

\section{Big Data and Its Characteristics}

Alvin Toffler coined the term "big data" in 1980, in a book titled "Third Wave." Big data then has taken on a new meaning in the era of the Internet, cloud computing, and other emerging technologies (Guo T. \& Wang Y., 2019). The term "Big Data" also refers to the evolution and application of technologies that enable the right user to receive the right information at the right time from a mass of data that has been growing exponentially in our society for a long period. The difficulty is not only in dealing with rapidly growing data volumes but also in managing increasingly heterogeneous data formats and increasingly complex and interconnected data. As a complex polymorphic object, its definition varies according to the communities interested in it as a user or provider of services. Invented by the web's giants, Big Data presents itself as a solution that enables realtime access to massive databases for everyone. Big Data is a notoriously difficult concept to define precisely, as the definition of "big" in terms of data volume varies considerably across industries. It is not defined by a particular set of technologies; rather, it is defined by a class of techniques and technologies. This is a developing 
field, and as we learn how to apply this new paradigm and capitalize on its value, the definition is evolving (Riahi Y. \& Riahi S., 2018).

According to Hariri R.H. et al. (2019), there are numerous characteristics of big data that are denoted by the letter "V," but we can also refer to the five most prevalent characteristics of big data as Volume, Veracity, Velocity, Variety, and Value, as illustrated in Figure 1.

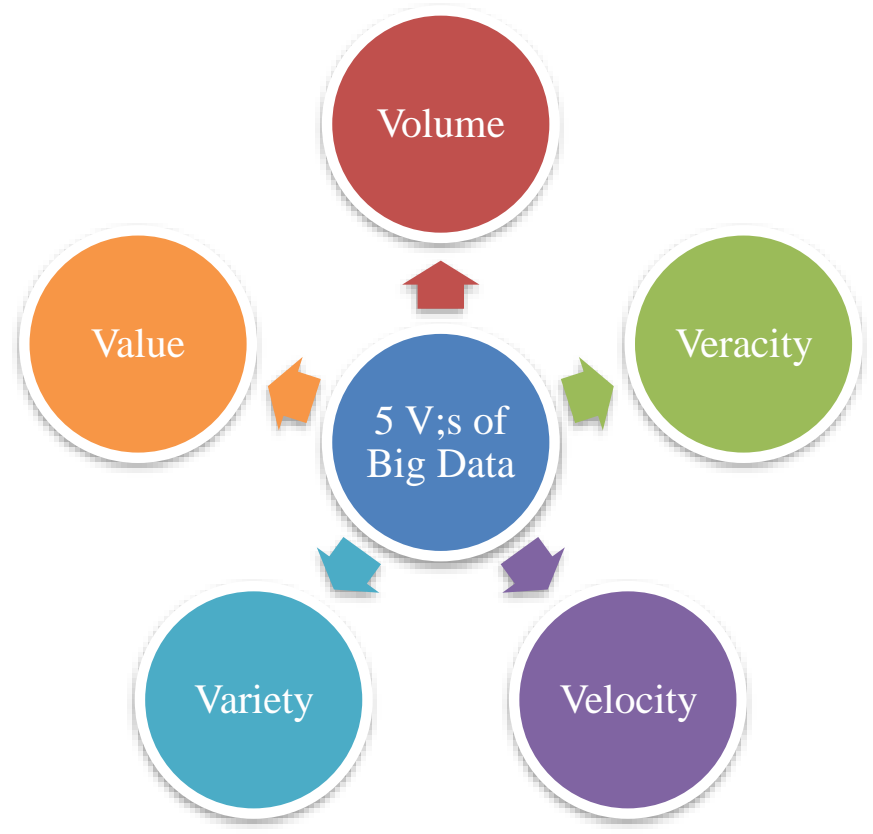

Figure 1: Common Big Data Characteristics

(Source: Hariri R.H. et al., 2019)

Volume is a term that refers to the enormous amount of data generated every second and is used to describe the size and scope of a dataset. It is impractical to define a universal threshold for the volume of big data because the time period and type of data affect its definition (Gandomi A. \& Haider M., 2015). The increase in volume is explained not only by the growth in the amount of data generated and stored, but also by the increasing need to exploit it (Riahi Y. \& Riahi S., 2018). At the moment, datasets in the exabyte $(\mathrm{EB})$ or zettabyte $(\mathrm{ZB})$ range are commonly referred to as big data (however, challenges still exist for datasets in smaller size ranges). Such massive data sets can introduce scalability and uncertainty issues (such as a database tool may not be able to accommodate infinitely large datasets). Numerous existing data analysis techniques are not optimized for large-scale databases and may fall short when attempting to scan and comprehend large amounts of data (Tsai CW et al., 2015).

The term "Variety" refers to the various types of data contained in a dataset, which may include structured data, semi-structured data, and unstructured data. This multiplication results in an increase in the complexity of the links and link types that exist between these data. The variety also refers to the potential applications of raw data (Riahi Y. \& Riahi S., 2018). While structured data is typically well- 
organized and easy to sort, unstructured data (for example, text and multimedia content) is unorganized and difficult to analyze. Semi-structured data (e.g., NoSQL databases) uses tags to denote data elements, but the database user is responsible for enforcing this structure. Uncertainty can manifest itself during data conversions between different data types, in the representation of mixed data types, and in runtime changes to the dataset's underlying structure (Hariri R.H. et al., 2019). From a variety standpoint, traditional big data analytics algorithms face difficulties when dealing with multi-modal, incomplete, and noisy data. Due to the fact that these techniques are designed to work with well-formatted input data, they may be unable to work with incomplete and/or different input data formats (Pokorný J. et al., 2015).

Velocity refers to the rate at which data is processed (in batch, near-real-time, realtime, or streaming mode), emphasizing that the rate at which data is processed must match the rate at which data is produced (Chen M et al., 2014). Additionally, it denotes the rate at which data is generated, captured, and shared (Riahi Y. \& Riahi S., 2018). For instance, Internet of Things (IoT) devices generate massive amounts of sensor data continuously. Devices in the cyber-physical domain frequently rely on real-time operating systems that enforce strict execution timing standards, and as such, may encounter issues when data provided by a big data application is delayed (Jain A., 2016).

Veracity is a measure of the data's quality (such as uncertain or imprecise data). Due to the fact that data can be inconsistent, noisy, ambiguous, or incomplete, it is classified as good, bad, or undefined. Due to the increasing diversity of data sources and types, establishing accuracy and trust in big data analytics becomes more difficult. For instance, an employee may use Twitter to share official corporate information but also to express personal opinions, posing difficulties for any technique designed to work with the Twitter dataset (Riahi Y. \& Riahi S., 2018).

Value conveys the context and usefulness of data for decision-making, whereas the preceding Vs emphasize the challenges inherent in big data. For instance, Facebook, Google, and Amazon have all incorporated the value of big data into their respective products via analytics. Amazon analyzes large datasets of users and their purchases to provide product recommendations, resulting in increased sales and user engagement. Google collects location data from Android users in order to improve Google Maps' location services. Facebook tracks user behavior in order to deliver targeted advertising and friend recommendations (Hariri R.H. et al., 2019). Each of these three companies has grown to enormous size by analyzing large amounts of raw data and extracting and retrieving useful insight to help businesses make better business decisions (Court D., 2015).

\section{Big Data and Customer Engagement}

Big data has also revolutionized the corporate landscape in the last few years, presenting businesses with both opportunities and difficulties. Using big data to enhance the process of building, growing, and fostering deeper consumer 
engagement has become a critical area of business and research. Due to their capacity to acquire, analyze, and communicate massive amounts of customer intelligence via Big Data techniques, information and communication technologies provide enterprises with significant potential to engage with customers. Additionally, these approaches create multiple chances for organizations to capture the value generated by consumer engagement behaviors, while also developing advanced competencies that enable enterprises to sustain value creation over time (Kunz, W. et al., 2017).

Customer involvement has long been acknowledged as a critical factor in a business's financial success. Many businesses invest in engagement on the assumption that it will result in favorable financial results - yet this is very dependent on an organization's ability to establish effective interactions with its customers. To do this, it is vital to grasp the customer's perspective on why, how, where, and when they wish to engage. Such motivations or orientations can differ significantly between clients, and a one-size-fits-all strategy is unlikely to produce desired results. For instance, the literature reveals that customers transmit information for a variety of reasons, including a sense of obligation, a desire to help others/altruism, and so on (Mazzarol T. et al., 2007). Additionally, it is critical to understand individuals' intrinsic tendencies for relationship formation (Hazan C. \& Shaver P. R., 1990).

However, according to DalleMule L. \& Davenport T.H. (2017), most businesses remain significantly behind the curve, with cross-industry studies indicating that less than half of an organization's structured data is actively used in decisionmaking, while less than $1 \%$ of unstructured data is analyzed or used at all. Additionally, more than $70 \%$ of employees have access to data they are not authorized to have, and $80 \%$ of a data analyst's effort is spent just identifying and preparing data. We're now confronted with new obstacles, whether it's crossdepartmental communication, providing competitive customer experiences, or making split-second judgments. Correctly capturing data about customers and users generates enormous benefits for enterprises across all industries, which is why businesses look for innovative data aggregation solutions that enhance that performance.

As a result, the requirement for Customer Data Management (CDM) is growing in order to conduct effective big data analysis. Customer data management (CDM) is the process of collecting, organizing, and analyzing data about customers. It's a critical mechanism when it comes to increasing customer acquisition, contentment, and retention rates, as well as customer visibility and communication tactics, as well as data quality and revenue growth (Heger R., 2020). Additionally, there are a number of reasons why developing a dependable customer database should be a top priority for every firm, particularly zakat institutions. To begin, gaining new zakat payers (muzakki) is not easy; yet, a customer database enables zakat institutions to communicate effectively without spending a fortune on ineffective, detached advertising. Thus, obtaining muzakki data simply by asking for it and then 
rewarding that trust by communication, events, and other promotional reminders creates a positive first impression and increases the possibility of having muzakki to pay zakat. Second, from a commercial perspective, an astounding $80 \%$ of sales originate from $20 \%$ of existing customers; therefore, by creating a healthy loyalty program that creates personalized, happy experiences, zakat institutions can generate recurring trust advocates who generate highly-valued word-of-mouth marketing. Only until a customer data management strategy is completely operational can the marketing team calculate critical metrics such as customer value over time, commonly known as Customer Lifetime Value (CLV) (Kellet S., 2020). Thirdly, gathering pertinent muzakki data enables zakat institutions to more precisely segment their target market, identify trends in payment behavior, and tailor individual communication tactics, resulting in more informed, real-time strategic decision-making. Fourth, the muzakki's journey to pay zakat can be lengthy and unexpected, involving several touchpoints, numerous gadgets, 24/7 consumption, and engagement both online and offline. Every stage of the zakat payment path can be studied to identify performers who can be aided in increasing zakat collection efficiency (Luenendonk M., 2020).

\section{RESEARCH METHODOLOGY}

The current study used an exploratory approach. Exploratory research is described as an investigation into a problem that is not well defined (Stebbins R., 2011). It is undertaken to gain a better knowledge of the current situation, but will not yield definite results. For this type of study, the researcher begins with a broad concept and uses it to find topics that can be the subject of future investigation (Heng Xu et al., 2006).

Additionally, this research included secondary research methodologies, which entailed compiling data from previously published primary research (Stebbins R., 2011). Several sources of information were used to compile this research, including online research and literature reviews. Online research is one of the quickest methods of accumulating information on any subject. Numerous datasets are easily accessible via the internet, and the researcher can download them as needed. While literature review is one of the most cost-effective methods for establishing a hypothesis. Libraries, online sites, articles on specific topics and even commercial databases all contain a wealth of knowledge which are all examples of sources (Neha Jain, 2021). In general, exploratory research is conducted when a subject requires in-depth understanding, particularly if it has not been addressed previously. The purpose of this type of study is to investigate the problem and the areas surrounding it, rather than to arrive at a conclusion. This type of research enables a researcher to lay a solid foundation for examining ideas, and identifying variables that are genuinely significant for future studies (Stebbins R., 2011).

\section{RESULT AND DISCUSSION}

This study proposes numerous forms of data to suit the requirements of big data analytics, including identity data, quantitative data, descriptive data, and qualitative data. 


\section{Identity Data}

By gathering the muzakki's identity data, zakat institutions may be able to create a unique profile for them that includes the essential facts necessary to construct a foundation, as well as any contact information necessary to reach out to them. Once the muzakki persona is established, communication can be tailored to their unique specialty and stage in the zakat payment path. Examples of personal identification information include the following:

Table 1. Muzakki’s Identity Data

\begin{tabular}{|c|c|c|c|}
\hline No. & $\begin{array}{c}\text { Types of } \\
\text { Identity } \\
\text { Data }\end{array}$ & Examples & $\begin{array}{c}\text { How to Collect the } \\
\text { Data }\end{array}$ \\
\hline 1 & Name & Title, First Name, Last Name & $\begin{array}{l}\text { - Customized sign- } \\
\text { up forms }\end{array}$ \\
\hline 2 & Personal & $\begin{array}{l}\text { Identification No., Passport No., } \\
\text { Date of Birth, Region, Gender }\end{array}$ & $\begin{array}{l}\text { Possibilities for } \\
\text { pre-zakat }\end{array}$ \\
\hline 3 & Address & $\begin{array}{l}\text { Email address, Home address, } \\
\text { Billable address }\end{array}$ & $\begin{array}{l}\text { payment } \\
\text { - Process for }\end{array}$ \\
\hline 4 & Telephone & Home no., Work no., Cell Phone no. & $\begin{array}{l}\text { creating a } \\
\text { customized e- }\end{array}$ \\
\hline 5 & $\begin{array}{c}\text { Social } \\
\text { Network }\end{array}$ & Facebook, Twitter, LinkedIn & $\begin{array}{l}\text { Commerce } \\
\text { website }\end{array}$ \\
\hline 6 & Account & User Ids, Payment Preferences & $\begin{array}{l}\text { Programs of } \\
\text { loyalty/rewards }\end{array}$ \\
\hline
\end{tabular}

Typically, any organizations collect this type of data when customers submit their payment information during the checkout process, sign up for a newsletter, or voluntarily provide it in exchange for a product, service, or reward. As is always the case, this is true for any zakat institution that always maintains a basic muzakki recording system.

\section{Quantitative Data}

Once zakat institutions have gained an understanding of the muzakki on an individual level, it is critical to understand how the muzakki as a customer interacts with zakat institutions through the use of quantifiable operational data, or quantitative data. Quantitative data is information gathered throughout the customer journey, down to the smallest details about the discovery process, multiple channel interactions, and conversion-specific procedures that may have resulted in the zakat payment. Quantitative data examples include the following:

Table 2. Muzakki's Quantitative Data

\begin{tabular}{|c|c|c|c|}
\hline No. & $\begin{array}{c}\text { Types of } \\
\text { Quantitative }\end{array}$ & Examples & $\begin{array}{c}\text { How to Collect the } \\
\text { Data }\end{array}$ \\
\hline
\end{tabular}




\begin{tabular}{|c|c|c|c|}
\hline 1 & $\begin{array}{c}\text { Online/ } \\
\text { Offline } \\
\text { Transactions }\end{array}$ & $\begin{array}{l}\text { Type of zakat paid, amount of } \\
\text { zakat paid, time of payment } \\
\text { made, End of hawl date, } \\
\text { Amount of calculated nisab, } \\
\text { Any specific asnaf's target }\end{array}$ & $\begin{array}{l}\text { Web analytics tools, } \\
\text { such as Google } \\
\text { Analytics }\end{array}$ \\
\hline 2 & $\begin{array}{c}\text { Inbound/ } \\
\text { Outbound } \\
\text { Communicati } \\
\text { on }\end{array}$ & $\begin{array}{l}\text { Date, Time, Channel, Opens, } \\
\text { Click Through Rates }\end{array}$ & $\begin{array}{l}\text { Cookies/mouse- } \\
\text { tracking heatmaps on } \\
\text { landing pages } \\
\text { - Pixels for tracking in } \\
\text { emails/newsletters }\end{array}$ \\
\hline 3 & $\begin{array}{l}\text { Online } \\
\text { Activity }\end{array}$ & $\begin{array}{l}\text { Website visits, Zakat } \\
\text { information views, Account } \\
\text { registration, Asnaf distribution } \\
\text { information views }\end{array}$ & $\begin{array}{l}\text { Keeping track of } \\
\text { previous payment } \\
\text { transactions } \\
\text { - Keeping track of } \\
\text { previous customer }\end{array}$ \\
\hline 4 & $\begin{array}{l}\text { Social } \\
\text { Network }\end{array}$ & $\begin{array}{l}\text { Social handles, Groups, } \\
\text { Interactions, Interests }\end{array}$ & $\begin{array}{l}\text { support } \\
\text { communications } \\
\text { - Social media }\end{array}$ \\
\hline 5 & $\begin{array}{l}\text { Customer } \\
\text { Service }\end{array}$ & $\begin{array}{l}\text { Complaint details, Muzakki } \\
\text { query details, Call Center, or } \\
\text { Email communication }\end{array}$ & interactions \\
\hline
\end{tabular}

The quantitative data will be used to better understand how muzakki (as a customer) decides when interacting with zakat institutions. How did they come upon the zakat institution? Which channel generates the greatest number of conversions? Throughout the zakat payment lifecycle, channel-specific technologies are available and should be adjusted to measuring zakat marketing goals and strategy.

\section{Descriptive Data}

In addition to identity data, descriptive data is used to acquire extra demographic information about muzakki personalities. Once this is understood, zakat institutions will be one step closer to using optimal timing in their marketing activities through predictive analysis. The following are some examples of descriptive data:

Table 3. Muzakki's Descriptive Data

\begin{tabular}{|c|c|c|c|}
\hline No. & $\begin{array}{c}\text { Types of } \\
\text { Descriptive } \\
\text { Data } \\
\end{array}$ & Examples & $\begin{array}{c}\text { How to Collect the } \\
\text { Data }\end{array}$ \\
\hline 1 & Family & $\begin{array}{l}\text { Marital Status, Relationships, } \\
\text { Number of Children }\end{array}$ & $\begin{array}{l}\text { Interview questions } \\
\text { that are not closed- }\end{array}$ \\
\hline 2 & Lifestyle & $\begin{array}{l}\text { Property Type, Car, Pet } \\
\text { Ownership, Hobbies, } \\
\text { Collections, Interests }\end{array}$ & $\begin{array}{l}\text { ended } \\
\text { - Questionnaires and } \\
\text { surveys in-depth }\end{array}$ \\
\hline
\end{tabular}




\begin{tabular}{cl}
3 Education & $\begin{array}{l}\text { High School, College, } \\
\text { Advance Education } \\
\text { Job Title, Job Description, }\end{array}$ \\
$4 \quad$ Career & $\begin{array}{l}\text { Income, Professional } \\
\text { Background }\end{array}$ \\
\hline
\end{tabular}

Obtaining high-quality descriptive data is a difficult task that requires further creativity. Typically, organizations collect data through in-depth questionnaires that delve into seasonal growth and decline, payment practices, and the duration of the muzakki's zakat payment cycle.

\section{Qualitative Data}

Qualitative data should describe the rationale for muzakki's zakat payment choices. Typically, questions will begin with How, Why, and How, such as "how attitudes and beliefs are formed," "why individuals behave the way they do," and "what are the differences between social groups." Qualitative data examples include the following:

Table 4. Muzakki's Qualitative Data

\begin{tabular}{|c|c|c|c|}
\hline No. & $\begin{array}{c}\text { Types of } \\
\text { Qualitative } \\
\text { Data }\end{array}$ & Examples & How to Collect the Data \\
\hline 1 & Attitudinal & $\begin{array}{l}\text { Perceived Value, Rating, } \\
\text { Feedback, Repayment } \\
\text { (zakat) Likelihood }\end{array}$ & $\begin{array}{l}\text { - Industry-specific review } \\
\text { websites } \\
\text { - Social listening via social } \\
\text { media monitoring tools }\end{array}$ \\
\hline 2 & Motivational & $\begin{array}{l}\text { Reason for Zakat } \\
\text { Payment, Customer Needs }\end{array}$ & $\begin{array}{l}\text { - Tailored newsletter sign-up } \\
\text { process } \\
\text { - Using a favorite, save, or } \\
\text { rating system }\end{array}$ \\
\hline 3 & Opinion & $\begin{array}{l}\text { Likes/Dislikes, } \\
\text { Preferences }\end{array}$ & $\begin{array}{l}\text { Profound listening and } \\
\text { feedback in the form of } \\
\text { questions. }\end{array}$ \\
\hline
\end{tabular}

Qualitative data collection can be time demanding, as gaining deep insight into muzakki behaviors takes more effort and is, therefore, more expensive than collecting quantitative data. Regardless of the method used, accessible options include direct connection with muzakki on a one-to-one basis, direct interaction with individuals in a group setting, or indirect interpretation of muzakki opinions via various communication channels along the muzakki journey. 

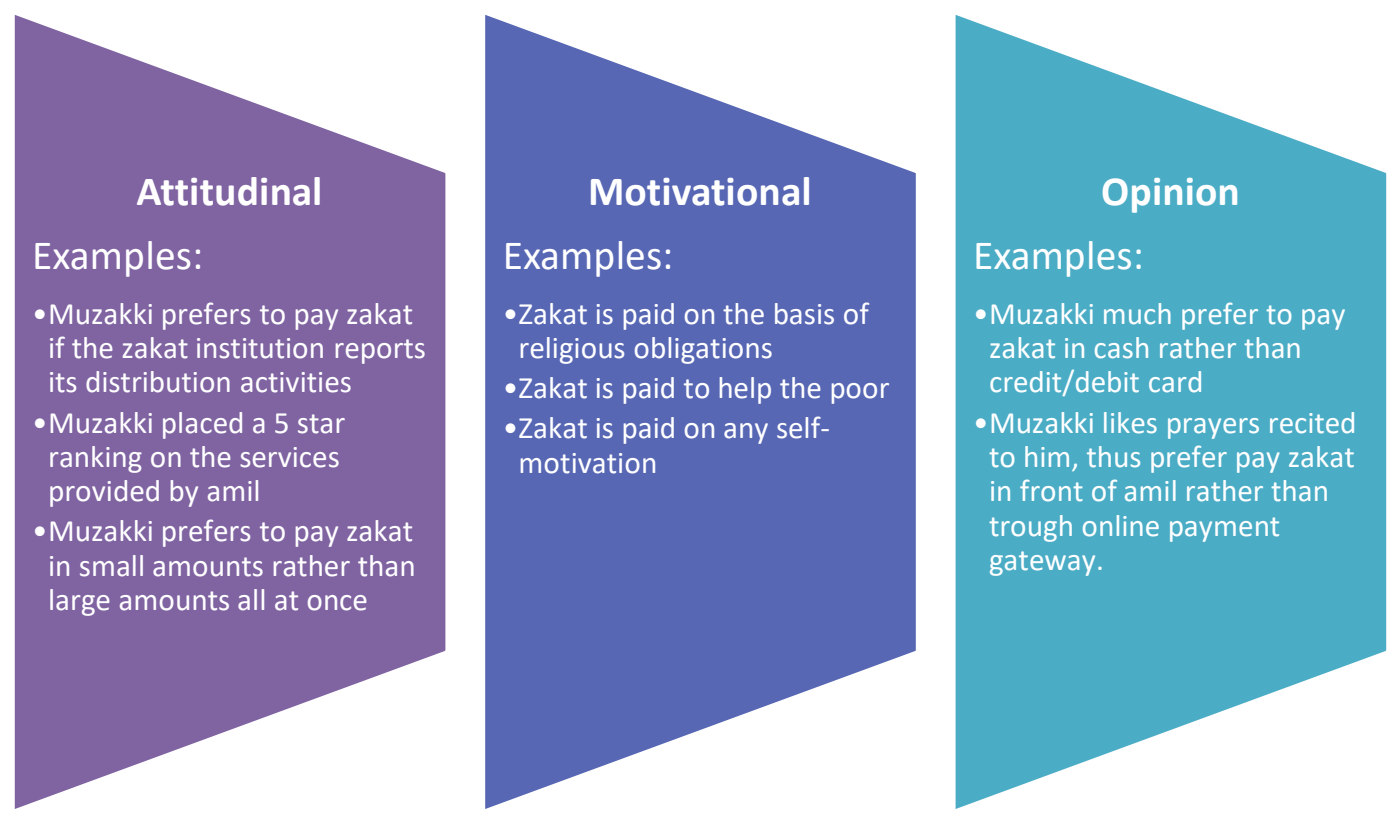

Figure 1. Some Examples of Real Data for Muzakki's Qualitative Data

\section{DATA MANAGEMENT TOOL}

At first glance, manually saving data on Excel sheets or other spreadsheet applications may appear to be a cost-effective alternative. However, when an organization grows, the data it collects grows as well, and the organization may become lost in the complicated, voluminous data sets presented by today's big data trend, not to mention a dearth of key insights that could provide the institution with a competitive edge. That, however, may not be the greatest threat to zakat collecting. Ignoring initial zakat payers and their Customer Lifetime Value (CLV) in favor of new ones is the underlying problem (Kellet S., 2020). Zakat institutions may require efficient software to store, track, and make sense of all incoming data sooner rather than later. Though it is as prudent to invest in the appropriate tools from the start, rather than having to modify once zakat institutions encounter lost muzakki, tarnished reputations, and the limits of a spreadsheet. There are numerous customer data management software solutions available for storing customer data, but one stands out for enabling the scale of personalization that many consumers now expect: Customer Relationship Management (CRM), Data Management Platform (DMP), and Customer Data Platform (CDP) (Heger R., 2020).

\section{Customer Relationship Management (CRM)}

Customer Relationship Management (CRM) is a platform that originated in the 1990 s as the first data aggregation platform. As a customer data management system, their main function was to collect known characteristics about customers (first-party data) and manage these interactions - think Identity and Quantitative data rather than Descriptive and Qualitative data (Sowards A., 2019). CRM has a number of advantages, including the fact that CRM platforms are designed to engage existing customers, gathering key data to fuel greater customer service, sales 
initiatives, and more informed marketing agendas. This is the first step toward collecting data that is well-organized and available to many departments for the purpose of monitoring customer interactions with zakat institutions. Numerous marketing chores, such as lead generation through sign-up forms and quick reporting, may be automated swiftly using a CRM (Gaille B., 2015). With improved time management, more time can be spent on more critical details. Additionally, CRMs may readily link with external tools to help create marketing strategies and collect additional data (Stobierski T., 2017).

However, CRM systems have some shortcomings in that they were never designed to learn about visitors before they become customers (or payers), making achieving the Single Customer View a difficult and admittedly expensive endeavor when social media channels, advertising campaigns, web behavioral data, and other data sources are included (Stobierski T., 2017). Additionally, CRMs lack the majority of real-time functionality, since they excel at managing tens of actions, thousands or even millions of times, but are not as adaptive. The more personalized a CRM becomes, the more disorganized and unmanageable it becomes (Heger R., 2020).

\section{Data Management Platform (DMP)}

In the 2000s, as the Internet became increasingly trackable, an alternative data aggregation platform emerged. Through the use of cookies, the Data Management Platform (DMP) catered to advertisers and aided in the design and implementation of media campaigns. Unlike CRMs, DMPs attempted to unify anonymous IDs by utilizing data sources that might be purchased (second and third-party data) rather than collecting them independently (first-party data). DMPs have some advantages in that they enable organizations to segment users by stitching together bits and pieces of second- and third-party data from cookies and other behavioral data. These parts can then be swiftly included into media personalization and dynamic advertising (Matuszewska K., 2018). However, because DMPs can only hold anonymous, third-party data with limited segmentation, they are significantly outclassed when it comes to performing more exact identification matching. Thus, establishing a unified customer view with cross-departmental collaboration is ruled out. Additionally, data from DMPs is transient, depending on the 90-day lifespan of a cookie, not to mention the decreased effectiveness of cookies following GDPR implementation. Integrating a DMP into an organization's existing environment might be difficult. It necessitates a high level of technical and domain understanding. Such data aggregation technologies may prove to be too sophisticated for staff to use effectively, resulting in a steep learning curve (Heger R., 2020).

\section{Customer Data Platform (CDP)}

As the Big Data movement grew in popularity, so did the data troves, necessitating the need for flexibility and scale capable of meeting the demand for enhanced customer experience and omni-channel marketing campaigns. As the newest player among aggregated data platforms, the Customer Data Platform (CDP) connects seamlessly with existing data, combining first-, second-, and third-party data, as 
well as offline and unstructured data, into a single system. While CRMs and DMPs also support segmentation, the primary benefit of CDPs is their ability to centralize all customer data entering businesses, regardless of the channel or device utilized by the customer. It centralizes all data acquired around the client, rather than the channel or device from which it was collected. The more data sources a business has to draw from, the more powerful the CDP may be (Early S., 2018). A CDP is the beating heart of customer data, enabling the creation of a Single Customer View. Additionally, CDPs provide real-time data streaming, allowing for immediate action throughout the customer journey, such as personalized recommendations, audience activation, and frequent cross- and up-selling opportunities. At this scale, flexibility may be applied to a variety of channels and purposes, resulting in a more actionable marketing endeavor. CDP was likewise created with marketers in mind, not IT developers. Due to the all-in-one nature of CDPs, they connect seamlessly with current zakat institutions' environments, eliminating the need for specific integrations across numerous modules. By consolidating numerous data sources into a single source of customer information, quick cross-departmental communication is facilitated, resulting in a linked customer experience across all channels via the same interface (Matuszewska K., 2018; Heger R., 2020).

One of CDP's weaknesses is that it is based on first-party data, which means it is nearly entirely reliant on data obtained through an organization's marketing operations. While it is more tailored and is based on actual client information, all of this information must be acquired, and the company may find itself short of the data required to operate marketing activities at full speed. In comparison to DMPs, however, limitations on data sets include the inability to include external data sources, such as second- and third-party data sets, into marketing efforts (Heger R., 2020).

\section{THEORITICAL CONTRIBUTIONS}

This research is providing a revelatory in theoretical contribution. Corley \& Gioia (2011), define revelatory in theoretical contribution as a term describing how the theory would increase existing knowledge. Additionally, it is believed that theory must reveal previously unknown truths about phenomena. Thus, this research may result in the development of new theories (Zhou, J., et al., 2017).

In the framework of zakat research, the outcomes of the case studies indicate that many types of data can be used to conduct big data analysis in order to boost zakat collection, particularly in the area of muzakki data. Along with monitoring the muzakki data as it grows, the zakat institution is responsible for utilizing it to improve their zakat collection. Additionally, this research demonstrates that different branches of analysis can be conducted based on the zakat data obtained, and that if the various data are successfully collected and analyzed together using an appropriate data management system, a big data analysis can aid in the decisionmaking process. 
According to the preceding paragraph, it would be beneficial to investigate how zakat initiators, ICT specialists, managers, and decision-makers interact with muzakki's data and the rest of the community. Additionally, this form of research enables future researchers to provide a firm foundation for examining concepts and finding variables that are truly essential for future studies.

\section{PRACTICAL IMPLICATIONS}

It has been acknowledged that zakat is a personal form of devotion, although it is generally managed through organizations referred to as zakat institutions. The zakat Institution is also responsible for exploiting the Muzakki data to better their zakat collection. If zakat institutions have access to relevant Muzakki data, they can better target their market, recognize payment trends, and develop customized marketing approaches, which allows them to make more informed, real-time strategic decisions. In the future, access to mountains of Muzakki's data will demand that the zakat institution (i.e., the zakat collection and management agency) develop more effective business plans and judgments.

Understanding the strategic significance of data and the decisions that may be taken as a result of data analysis is crucial for employees at zakat institutions, since many of them are unaware of these facts. The important zakat collection and management data is improved using big data, making it a valuable strategic option for the institution. Still, by taking note of the Muzakki's demographic information, we may be able to create a profile with vital details and contact information to aid in establishing a foundation and locating them. When zakat institutions have a good understanding of the muzakki persona, they may target their individual needs and stages, and speak to them like a customer or patron.

\section{CONCLUSION}

A large customer database cannot be developed overnight; it takes time and effort on the part of zakat institutions to collect the appropriate data, determine the appropriate method of storage, and implement the essential protections for proper use. If done properly now, this information will eventually become a benefit to zakat institutions, assisting them in growing and succeeding in zakat-related efforts. However, if neglected, it may bite back. This is why it is critical to have a wellmaintained, accessible, and insightful muzakki data system, which can be accomplished with the use of a strong customer data platform.

In addition to handling the accumulating muzakki data, the zakat institution is responsible for utilizing it to improve their zakat collection. As a result, the present rate of growth in the amount of data acquired is astounding. A significant challenge for the zakat institution's IT department is that this growth rate is rapidly outpacing the institution's ability to manage its data effectively and analyze the zakat data to extract meaningful meaning for improved decision making in order to ensure more effective zakat collection measures. Still, by gathering the muzakki's data, we're might be able to create a unique profile for them, complete with the essential facts necessary to construct a foundation and any contact information necessary to reach 
out to them. Once the muzakki persona is defined, communication may be tailored to their unique niche and position in the customer journey.

The big data analytical process is crucial for employee training, as many zakat institution employees are unaware of the value of data and the strategic decisions that may be taken as a result of data analysis. Thus, big data serves as a vital strategic solution for the zakat institution, optimizing and ensuring the proper management of critical data related to zakat collection and management. However, this study only proposes a preliminary concept of muzakki data requirements for big data analytics in order to improve zakat collection by zakat institutions. Additional study must be conducted in order to begin applying the data acquired into big data analysis for zakat strategic decision making.

\section{REFERENCES}

Awwad, M. S., \& Omoush, K. S. A. (2012). Governance of Information Technology-Business Relationship Quality and Performance Outcomes. Electronic Government, an International Journal, 9(4), 350-369.

Bhadani, A., \& Jothimani, D. (2016). Big Data: Challenges, Opportunities and Realities, In Effective Big Data Management and Opportunities for Implementation (1-24). Pennsylvania, USA: IGI Global.

Chen, M., Mao, S., \& Liu, Y. (2014). Big Data: A Survey. Mobile Network and Applications 19 (2), 171-209.

Corley, K. G., \& Gioia, D. A. (2011). Building theory about theory building: what constitutes a theoretical contribution? Academy of Management Review, 36 (1), 12-32.

Early, S. (2018). The Role of a Customer Data Platform. IT Professional 20 (1):6976. https://doi.org/10.1109/MITP.2018.011301803

Gaille, B. (2015, October 30). 12 Pros and Cons of Customer Relationship Management. Brandongaille. https://brandongaille.com/12-pros-and-consof-customer-relationship-management/

Gandomi A, \& Haider M. (2015). Beyond The Hype: Big Data Concepts, Methods, and Analytics. International Journal of Information Management 35(2), 13744.

Guo, T., \& Wang, Y. (2019). Big Data Application Issues in the Agricultural Modernization of China. Ekoloji Dergisi, 28(107), 3677-3688.

Hariri, R.H., Fredericks, E.M. \& Bowers, K.M. (2019). Uncertainty in Big Data Analytics: Survey, Opportunities, and Challenges. Journal of Big Data 6, 44. https://doi.org/10.1186/s40537-019-0206-3

Halper, F., \& Krishnan, K. (2013). TDWI Big Data Maturity Model Guide: Interpreting Your Assessment Score. TDWI Benchmark Guide. https://tdwi.org/ /media/3BF039A2F7E1464B8290D8A9880FEC22.pdfma

Hazan, C., \& Shaver, P. R. (1990). Love and Work: An Attachment-Theoretical Perspective. Journal of Personality and Social Psychology, Vol. 59 No. 2, 270-280. 
Heger R. (2020, March 1). Customer Data Management: How to Gather Customer Data Correctly. Bloomreach. https://exponea.com/blog/customer-datamanagement/

Heng X., Teo HH., \& Tan, B. (2006). Information Privacy in the Digital Era: An Exploratory Research Framework. Americas Conference on Information Systems (AMCIS) Proceedings, 900-906.

Jain A. (2016, September 17). The 5 Vs of Big Data. IBM Watson Health Perspectives. IBM. https://www.ibm.com/blogs/watson-health/the-5-vs-ofbig-data/

Kellet S. (2020, December 6). What's Customer Lifetime Value - All You Need To Know (The Ultimate 2021 Guide). Bloomreach. https://exponea.com/blog/customer-lifetime-value-guide/

Kunz, W., Aksoy, L., Bart, Y., Heinonen, K., Kabadayi, S., Villaroel Ordenes, F., Sigala, M., Diaz, D., \& Theodoulidis, B. (2017). Customer Engagement in a Big Data World. Journal of Services Marketing, 31 (2), 161-171.

Lubis, M., Yaacob, N. I., Omar, Y., Dahlan, A., \& Rahman, A. (2011). Enhancement of zakat distribution management system: case study in Malaysia. International Management Conference 2011 Proceedings, 1-10. University Sultan Zainal Abidin.

Luenendonk M., (2020, September 29). What Is a Sales Funnel? The Guide to Building an Automated Selling Machine. FounderJar. https://www.founderjar.com/sales-funnel/

Matuszewska K., 2018. Find the most suitable data gathering platform - pros and cons of DMPs, CDPs, DWs and CRMs. Piwikpro. https://piwik.pro/blog/datagathering-platform-dmp-cdp-dw-crm/

Mazzarol, T., Sweeney, J. C., \& Soutar, G. N. (2007). Conceptualizing Word-OfMouth Activity, Triggers and Conditions: An Exploratory Study. European Journal of Marketing Vol. 41 No. 11/12, 1475-1494.

McKinsey \& Company. 2020. The Next Normal The Recovery Will Be Digital Digitizing At Speed and Scale. McKinsey Global Publishing.

MN Paizin. (2014). Practice of Da'wah in Zakat (Islamic Alms) in Federal Territory, Malaysia: An Observation. International Proceedings of Economics Development and Research Vol. 73. http://www.ipedr.com/vol73/007-ICWIS2014_A00018.pdf

MN Paizin. (2017). Usage of Islamic Alms's Online Portal: Case Study on Pusat Pungutan Zakat (PPZ), Federal Territories of Malaysia. Intellectual Property Rights: Open Access, Volume 5, Issue 1. https://doi.org/10.4172/2375$\underline{4516.1000175}$

MN Paizin, \& S. Sarif. (2021 April). Limitasi Penggunaan Konsep Wakalah dalam Sistem Pengurusan Zakat di Malaysia. e-Jurnal Penyelidikan dan Inovasi Vol 8 No. 1, 198-220. http://rmc.kuis.edu.my/jpi/wp-content/uploads/2021/04/8April-2021.pdf

Neha Jain. (2021). Survey Versus Interviews: Comparing Data Collection Tools for Exploratory Research. The Qualitative Report 2021 Volume 26, Number 2, 541-554. https://doi.org/10.46743/2160-3715/2021.4492 
Nugraha F., Permadia S., Gunawan A.R., \& Saeful E. (2019). Artificial Intelligence Usage in Zakat Optimization. International Conference of Zakat 2019 Proceedings, 14-24.

Pokorný J., Škoda P, Zelinka I, Bednárek D, Zavoral F, Kruliš M, \& Šaloun P. (2015). Big Data Movement: A Challenge in Data Processing. In Big Data in Complex Systems. Cham: Springer, 29-69.

PPZ. 2020. Laporan Tahunan 2020 Pusat Pungutan Zakat Majlis Agama Islam Wilayah Persekutuan. Kuala Lumpur: Pusat Pungutan Zakat.

Riahi, A., \& Riahi, S. (2015). The Big Data Revolution, Issues and Applications. International Journal of Advanced Research in Computer Science and Software Engineering (JARCSSE), Volume 5, Issue 8, 167-173.

Riahi, Y., \& Riahi, S. (2018). Big Data and Big Data Analytics: Concepts, Types and Technologies. International Journal of Research and Engineering Vol. 5 No. 9, September-October 2018, 524-528.

Sowards A. (2019). 8 Advantages and Disadvantages of Using Customer Relationship Management Software. Infinigeek. https://infinigeek.com/8advantages-disadvantages-using-customer-relationship-managementsoftware/

Stebbins, R.A. (2011). What Is Exploration? In: Exploratory Research in the Social Sciences. SAGE Publications, Inc. City: Thousand Oaks, 2-17.

Stobierski, T. (2017). What are the Pros and Cons of Using A CRM? Pepperland. https://www.pepperlandmarketing.com/blog/pros-and-cons-of-using-a-crm

Sulaiman, H., \& Jamil, N. (2014). Information Security Governance Model To Enhance Zakat Information Management in Malaysian Zakat Institutions. In Information Technology and Multimedia (ICIMU), 2014 International Conference on 2014 (pp. 200-205). IEEE.

Sulaiman, H., Che Cob, Z., \& Ali, N. (2015). Big Data Maturity Model for Malaysian Zakat Institutions to Embark on Big Data Initiatives. 4th International Conference on Software Engineering and Computer Systems (ICSECS), Kuantan, Pahang, Malaysia. August 19-21, 2015, 61-66.

Tsai, CW., Lai, CF., Chao, HC., et al. (2015). Big Data Analytics: A Survey. Journal of Big Data 2, 21. https://doi.org/10.1186/s40537-015-0030$\underline{3}$

Utami P., Suryanto T., Nasor M. \& Ghofur R.A. (2020). The Effect Digitalization Zakat Payment Against Potential of Zakat Acceptance in National Amil Zakat Agency. Iqtishadia Vol. 13 (2), 216-239.

Zhou, J., Shafique, M.N., Adeel, A., Nawaz, S., \& Kumar, P., (2017). What is Theoretical Contribution? A Narrative Review. Sarhad Journal of Management Sciences Vol. 3, Issue 2, 261-271. 